\title{
Gall-inducing Aphids (Hemiptera: Aphidoidea: Eriosomatinae) Associated with Salicaceae and Ulmaceae in Razavi Khorasan Province, with New Records for Fauna of Iran
}

\author{
A. NAJMI ${ }^{1}$, H. S. NAMAGHI ${ }^{1}$, S. BARJADZE ${ }^{2}$ and L. FEKRAT ${ }^{1}$ \\ ${ }^{1}$ Department of Plant Protection, Faculty of Agriculture, Ferdowsi University of Mashhad, Mashhad, Iran \\ ${ }^{2}$ Institute of Zoology, Ilia State University, Tbilisi, Georgia
}

(Received: 11 November 2018; accepted: 16 November 2018)

\begin{abstract}
A survey of gall-inducing aphids on elm and poplar trees was carried out during 2017 in Razavi Khorasan province, NE Iran. As a result, 15 species of gall-inducing aphids from 5 genera, all belonging to the subfamily Eriosomatinae, were recorded on 6 host plant species. The collected species included the genera Eriosoma, Kaltenbachiella, Pemphigus, Tetraneura and Thecabius. Pemphigus passeki Börner (Hemiptera: Aphididae) and Pemphigus populinigrae (Schrank) (Hemiptera: Aphididae) on Populus nigra var. italica (Salicaceae) were new records for the Iranian aphid fauna. Both new recorded species belong to the tribe Pemphigini, subfamily Eriosomatinae. Among the identified species, 8 aphid species were new records for Razavi Khorasan province.
\end{abstract}

Keywords: Aphid, elm, poplar, fauna, gall-inducing aphid.

Many insect groups, around 13,000 species, are known as plant gall makers (Nyman and Julkunen-Tiitto, 2000; Suzuki et al., 2009). Among them, Aphidoidea is a very large superfamily in the hemipteran suborder Sternorrhyncha with about 5000 known species (Blackman and Eastop, 2000; Ge et al., 2016). It is estimated that there are practically 10-20\% gallicolous aphid species nationwide (Chakrabarti, 2007; Chen and Qiao, 2012; Álvarez et al., 2013).

As an intricate process, the creation of gall dealing with growth activities comprising the recanalization and reorientation of plant development conduces to fractional or total insect encirclement, and the consequence is growth, maturation and reproduction of the insect inside the galls (Ananthakrishnan, 1984; Chakrabarti, 1987). It is conventional for any gall-forming species to merely impinge on one sort of tissue on one or a small number of plant species sharply associated. Insect genes managing the plant gall growth, results in distinctive particular gall shape that correlates with insect species (Nyman et al., 2000; Stone and Schönrogge, 2003; Suzuki et al., 2009). So, the combination of host plant species, site of gall forming and the shape of gall can be used to identify the species of gall inducer even when gall is empty (Floate, 2010). 
It is particularly the fundatrix which is capable of gall arousing on host plant in the vast majority of gall-inducing aphids (Wool and Burstein, 1991). Such distinguishing aphid morphs being only able of inspiring galls on special host plants (the primary host) at a specific time, cannot prevail galls upon their secondary hosts (Chakrabarti, 2007).

It is discovered that a large number of aphid agents inducing galls, are dioecious (or heteroecious). Such species constituting specific-size and shape galls, migrate from the tree species (the initial plants they subsist on) to roots of small plant or tree species (secondary hosts). There are scarcely ever monoecious aphid species whose their life cycle only takes place on one host species (Urban, 2002).

In Iran, cultivation of Populus nigra var. italica Münchh. is popular in most parts of central provinces, Azerbaijan, and Khorasan, and its growth is very satisfying in areas where adequate water is available. Species P. nigra L. is often planted near the bed of rivers and its wood is used by matchmaking factories. $P$. alba L. and its numerous varieties cultivate in steppe regions of Iran. The native species of northern forests of Iran is P. caspica (Bornm.) Bornm. from Talesh to Gorgan. P. euphratica Oliv. is resistant to drought and is distributed in arid and semi-arid regions of central, western and southwestern to Sistan region in eastern Iran. Since 1956, a number of different hybrids of $P$. $\times$ canadensis Moench. and $P$. deltoides Marshall have been imported from Turkey, the Netherlands and Italy to Iran (Khial and Sadraei, 1984).

Elm trees are often planted as ornamental trees in gardens and parks. There are two species of elm in Iran, often found in wet forests and steppe areas. Ulmus minor Mill., which is native to the European forests and also in the northern forests of Iran, from Arasbaran to Gorgan. Its wood is used in rural use for the beam and the pillar of the house. Ulmus minor 'Umbraculifera' is planted in Iran's gardens as a shade tree. Some scholars gave this elm to Turkmenistan and Russia, and some to Iran and Armenia. There are several varieties used in gardening to decorate gardens. Ulmus glabra Huds. is native to Europe and North America to Japan and is located in the middle and upper altitudes of the forests of northern Iran. In most of the Caspian forests extends from Arasbaran and Astara to Gorgan. This species is an industrial tree and is used in rural area for the provision of lacquer. Ulmus glabra was imported to Iran and cultivated in the Botanical garden of Karaj Agricultural College and from there introduced into other parts of Iran. This type is usually used to decorate the parks (Sabeti, 2002).

Revision of the relevant taxonomic documents (Tarasi et al., 2008; Alikhani et al., 2010; Nikdel and Dordaei, 2010; Hasanshahi et al., 2013; Barahoei et al., 2014; Ghafouri-Moghaddam et al., 2014; Rakhshani et al., 2015) indicated that there is still a lack of information from Iranian experts about galling aphids. Eight species appertaining to genus Pemphigus, have been reported from Iran up to the present. This research was carried out in Razavi Khorasan province, NE Iran where no previous faunistic study of gall-inducing aphids has been carried out.

\section{Materials and Methods}

This study was conducted during the growing season of 2017. The study area, Razavi Khorasan province (Fig. 1) is located in the North eastern Iran $\left(35.1020^{\circ} \mathrm{N}\right.$, $\left.59.1042^{\circ} \mathrm{E}\right)$, where no study had previously been carried out. The occurrence and distri- 


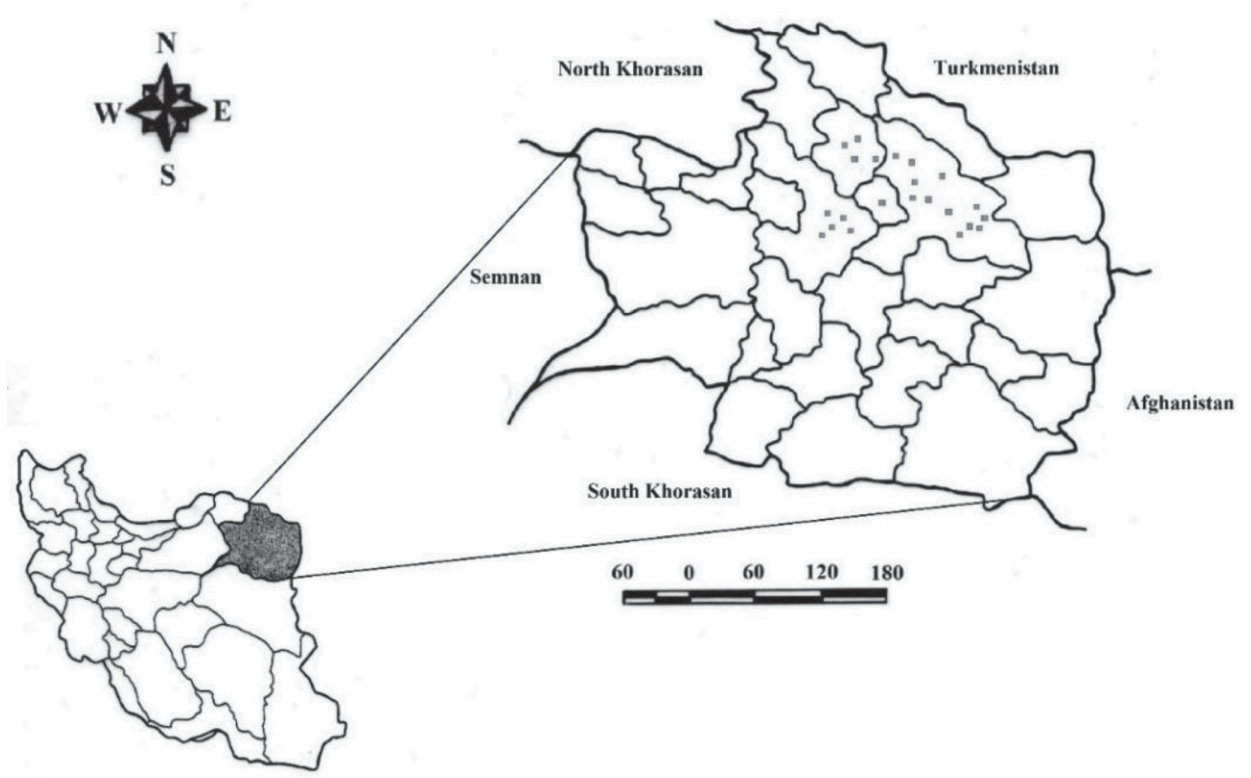

Fig. 1. Locations of sampling sites on map of Razavi Khorasan province, Iran

bution of gall aphids were studied by collecting galls containing aphid nymphs from host plants at each locality. The host plants and aphid-induced galls were put in separate small plastic bags and brought to the laboratory. Some species of host plants and aphid-induced galls were kept in rearing cages until the emergence of adult aphids. Moreover, some galls with aphids were put into vials filled with $75 \%$ alcohol for morphological studies. Plant species sampled for galling aphid species were: Populus nigra, P. nigra var. italica, Populus euphratica and Populus deltoides, Ulmus glabra and Ulmus minor which are their primary host. Geoposition coordinates were recorded with a hand-held GPS unit.

Sampling and preparation of aphid specimens were done according to the Blackman and Eastop (2018). Aphid species found on poplar trees were identified according to the Blackman and Eastop (2018) and approved by Dr. Roman Hałaj in Entomological Laboratory of the Upper Silesian Nature Society of Poland. The elm gall-inducing aphids were also identified and confirmed by the third author in Ilia State University of Georgia. Systematic knowledge, host plants, and synonyms of determined species were taken from Blackman and Eastop (2000, 2018). Voucher speciems as microscopic slides are held at the insect collection of Plant Protection Department of Agricultural College of Ferdowsi University of Mashhad, Iran.

\section{Results}

Fifteen gall-inducing aphid species belonging to the subfamily Eriosomatinae were found on six host plants. The occurrence of Pemphigus passeki Börner (Hemiptera: Aphididae) and Pemphigus populinigrae (Schrank) (Hemiptera: Aphididae) on Populus nigra in Iran are reported for the first time. 
List of species

Eriosoma lanuginosum (Hartig, 1839)

Material examined: Bibi Shatite - Neyshabur (36² $\left.13^{\prime} 05.9^{\prime \prime} \mathrm{N}, 58^{\circ} 46^{\prime} 39.7^{\prime \prime} \mathrm{E}\right)$, 18 May 2017, on Ulmus minor 'Umbraculifera'; Eram Park (36 $\left.16^{\circ} 34.7^{\prime} \mathrm{N}, 5^{\circ} 40^{\prime} 32.2^{\prime \prime} \mathrm{E}\right)$, 14 May 2017, on Ulmus minor; Khayyam Garden $\left(36^{\circ} 09^{\prime} 57.4^{\prime \prime} \mathrm{N}, 58^{\circ} 49^{\prime} 18.1^{\prime \prime} \mathrm{E}\right), 18$ May 2017, on Ulmus glabra; Nosrat Park (36 $\left.16^{\prime} 33.4^{\prime \prime} \mathrm{N}, 59^{\circ} 40^{\prime} 06.3^{\prime \prime} \mathrm{E}\right), 8$ May 2017, on Ulmus minor and Ulmus glabra; Paniz (36 $\left.6^{\circ} 15^{\prime} 38.9^{\prime \prime} \mathrm{N}, 5^{\circ} 39^{\prime} 10.9^{\prime \prime} \mathrm{E}\right), 5$ May 2017 , on Ulmus glabra; University Campus (36 $\left.18^{\prime} 22.4^{\prime \prime} \mathrm{N}, 59^{\circ} 31^{\prime} 59.9^{\prime \prime} \mathrm{E}\right), 20$ April 2017, on Ulmus minor; Raja Park (36 $\left.15^{\prime} 30.2^{\prime \prime} \mathrm{N}, 5^{\circ} 40^{\prime} 57.3^{\prime} \mathrm{E}\right), 25$ May 2017, on Ulmus minor and Ulmus glabra.

Published information: Malta-Girgenti, May 2006, alate inside gall on Ulmus canescens; Wied ir-Rum, July 2009, empty galls (Mifsud et al., 2009). In Belarus: Minsk Prov., on Ulmus minor; Brest Prov., on Ulmus minor and Ulmus glabra; Gomel prov., on Ulmus campestris (Buga et al., 2016).

Distribution in Iran: Caspian sea area, Tehran, West Azerbaijan and in all areas where Elm is present (Modarres Awal, 2002; Rezwani, 2004).

General distribution: Europe, the Mediterranean area and Asia east to Pakistan, introduced to South Africa (Blackman and Eastop, 2018).

\section{Eriosoma ulmi (Linnaeus, 1758)}

Material examined: Khayyam Garden (360'ㄷ․ $\left.4^{\prime \prime} \mathrm{N}, 5^{\circ} 49^{\prime} 18.1^{\prime \prime} \mathrm{E}\right), 18$ May 2017, on Ulmus glabra; Paniz (36 $\left.15^{\prime} 38.9^{\prime \prime} \mathrm{N}, 5^{\circ} 39^{\prime} 10.9^{\prime} \mathrm{E}\right), 5$ May 2017, on Ulmus glabra.

Published information: Bazeneh, June 2009 and Mohajeran, July 2009, on Ulmus sp. (Alikhani et al., 2010). On Ulmus villosa and Ulmus wallichiana, without any locality data (Singh and Singh, 2017). In Belarus: Minsk Prov., on Ulmus minor and Ulmus glabra; Gomel, on Ulmus glabra (Buga et al., 2016).

Distribution in Iran: Generally distributed (Modarres Awal, 2002).

General distribution: Europe including Iceland and Faroes, south-west and central Asia, Pakistan, India, eastward to Mongolia and China (Heie, 1993), and recently introduced to British Columbia, Canada (Foottit et al., 2006).

Kaltenbachiella pallida (Halliday, 1838)

Material examined: Bibi Shatite - Neyshabur (36² $\left.13^{\prime} 05.9^{\prime \prime} \mathrm{N}, 58^{\circ} 46^{\prime} 39.7^{\prime \prime} \mathrm{E}\right)$, 18 May 2017, Ulmus minor 'Umbraculifera'; Nosrat Park (36¹6'33.4”N, 59 40’06.3”E),

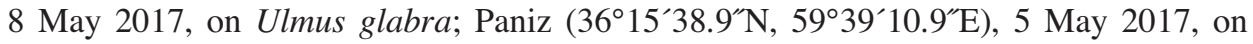
Ulmus glabra.

Published information: Mohajeran, July 2009, on Ulmus sp. (Alikhani et al., 2010). On Ulmus sp. without any locality data (Singh and Singh, 2017). In Belarus: Vitebsk Prov., on Ulmus glabra; Minsk, on Ulmus minor and Ulmus glabra (Buga et al., 2016).

Distribution in Iran: Northern and central provinces (Modarres Awal, 2002; Rezwani, 2004). This species is new record for Razavi Khorasan province.

General distribution: Europe and in north Africa, Middle East, south-west and central Asia, west Siberia, China, and reported also from Argentina (Ortego et al., 2004). 
Material examined: Basij Park (36 $\left.18^{\prime} 09.0^{\prime \prime} \mathrm{N}, 5^{\circ} 39^{\prime} 42.5^{\prime} \mathrm{E}\right), 28$ May 2017, on Populus nigra; Ghadamgah (36 $\left.06^{\prime} 43.9^{\prime} \mathrm{N}, 5^{\circ} 03^{\prime} 10.9^{\prime \prime} \mathrm{E}\right), 18$ May 2017, on Populus nigra var. italica; Sad Abad (36 $\left.16^{\prime} 58.8^{\prime \prime} \mathrm{N}, 58^{\circ} 52^{\prime} 14.0^{\prime \prime} \mathrm{E}\right), 18$ June 2017, on Populus nigra and Populus nigra var. italica; Pardis Qaem Park (36 21 $\left.21^{\prime} 01.5^{\prime \prime} \mathrm{N}, 59^{\circ} 33^{\prime} 38.9^{\prime \prime} \mathrm{E}\right), 14$ May 2017, on Populus nigra; Toroq Forest Park (36 $\left.15^{\prime} 06.1^{\prime \prime} \mathrm{N}, 5^{\circ} 37^{\prime} 02.3^{\prime \prime} \mathrm{E}\right), 7$ April 2017, on Populus nigra var. italica.

Published information: in Belarus: Minsk Prov.; August 2015, Populus balsamifera L. and July 2016, Populus $\times$ berolinensis Dippel. October 2016, Populus sp. September 2000, Populus laurifolia Ledeb. (Buga et al., 2016).

Distribution in Iran: Azerbaijan, Tehran, Markazi (Modarres Awal, 2002). Central Alborz, Karaj and Semnan (Rezwani, 2004). This species is new record for Razavi Khorasan province.

General distribution: Throughout the northern Palaearctic, from Sweden to China and Japan (Blackman and Eastop, 2018). Also, root-feeding populations of this species has been observed in Idaho (USA) (Hałaj and Osiadacz, 2013).

Pemphigus bursarius (Linnaeus, 1758)

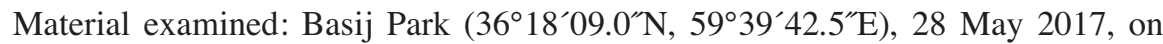
Populus nigra; Beheshte-reza $\left(36^{\circ} 09^{\prime} 57.2^{\prime} \mathrm{N}, 59^{\circ} 41^{\prime} 56.3^{\prime \prime} \mathrm{E}\right), 3$ June 2017, on Populus nigra; Bujan (36 14`31.3”N $58^{\circ} 58^{\prime} 09.2^{\prime \prime}$ E), 20 April 2017, on Populus nigra and Popu-

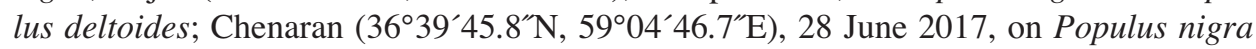
var. italica; Ghadamgah (36 $\left.06^{\circ} 43.9^{\prime \prime} \mathrm{N}, 5^{\circ} 03^{\prime} 10.9^{\prime \prime} \mathrm{E}\right), 18$ May 2017, on Populus nigra var. italica; Sad Abad (36 $\left.16^{\prime} 58.8^{\prime \prime} \mathrm{N}, 58^{\circ} 52^{\prime} 14.0^{\prime \prime} \mathrm{E}\right), 18$ June 2017, on Populus nigra and on Populus nigra var. italica; Olang (36 $\left.15^{\prime} 29.9 \mathrm{~N}, 5^{\circ} 48^{\prime} 06.6^{\prime \prime} \mathrm{E}\right), 5$ May 2017, on Populus nigra; Raja Park (36 $\left.15^{\prime} 30.2^{\prime \prime} \mathrm{N}, 59^{\circ} 40^{\prime} 57.3^{\prime \prime} \mathrm{E}\right), 28$ May 2017, on Populus nigra; Shirhesar $\left(36^{\circ} 36^{\prime} 05.8^{\prime} \mathrm{N}, 5^{\circ} 12^{\prime} 12.8^{\prime \prime} \mathrm{E}\right), 27$ May 2017, on Populus nigra; Toroq Forest Park $\left(36^{\circ} 15^{\prime} 06.1^{\prime \prime} \mathrm{N}, 5^{\circ} 37^{\prime} 02.3^{\prime \prime} \mathrm{E}\right), 7$ April 2017, on Populus nigra var. italica. Torghabeh $\left(36^{\circ} 18^{\prime} 33.3^{\prime \prime} \mathrm{N}, 5^{\circ} 22^{\prime} 58.7^{\prime \prime E}\right), 20$ July 2017, on Populus deltoides.

Published information: on Populus deltoides, Bazeneh, June 2009; Mohajeran, July 2009 (Alikhani et al., 2010). Brest Prov.: October 2016, Populus pyramidalis Borkh.; Gomel Prov.: July 2015, Populus nigra L.; Minsk, July 2014, Populus laurifolia Ledeb. (Buga et al., 2016). On Populus deltoides Marshall, Populus nigra var. italica Muench, Populus sp., Quercus sp. (Fagaceae), without any locality data (Singh and Singh, 2017).

Distribution in Iran: Azerbaijan, Kermanshah, Ilam, Guilan, Mazandaran, Golestan, Hamadan, Tehran, Markazi, Zanjan, Chahar Mahal and Bakhtiari (Modarres Awal, 2002), Ghazvin and Central Alborz (Rezwani, 2004). This species is new record for Razavi Khorasan province.

General distribution: Holarctic; Southern Africa, South America, Australia and New Zealand (Hałaj and Osiadacz, 2013). P. bursarius occurs in Europe, western and central Asia, northern and southern Africa, North and South America (Blackman and Eastop, 2018). 
Pemphigus immunis Buckton, 1896

(Syn.: Pemphigus lichtensteini Tullgren, 1909)

Material examined: Beheshte-reza $\left(36^{\circ} 09^{\prime} 57.2^{\prime \prime} \mathrm{N}, 59^{\circ} 41^{\prime} 56.3^{\prime \prime} \mathrm{E}\right), 3$ June 2017, on Populus nigra; Ghadamgah $\left(36^{\circ} 06^{\prime} 43.9^{\prime \prime} \mathrm{N}, 5^{\circ} 03^{\prime} 10.9^{\prime} \mathrm{E}\right), 18$ May 2017, on Populus nigra var. italica; Sad Abad (36 $\left.6^{\circ} 10^{\prime} 58.8^{\prime \prime} \mathrm{N}, 58^{\circ} 52^{\prime} 14.0^{\prime \prime} \mathrm{E}\right), 18$ May 2017, on Populus

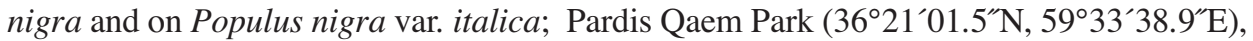

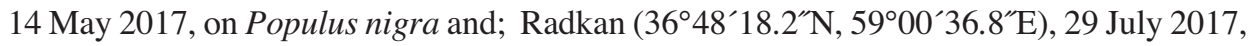
Populus euphratica; Raja Park (36 $\left.6^{\circ} 5^{\prime} 30.2^{\prime \prime} \mathrm{N}, 5^{\circ} 40^{\prime} 57.3^{\prime \prime} \mathrm{E}\right), 28$ May 2017, on Populus nigra; Toroq Forest Park (36 $\left.15^{\prime} 06.1^{\prime \prime} \mathrm{N}, 5^{\circ} 37^{\prime} 02.3^{\prime \prime} \mathrm{E}\right), 7$ April 2017, on Populus nigra var. italica; Torghabeh (36 $\left.16^{\circ} 33.3^{\prime} \mathrm{N}, 5^{\circ} 22^{\prime} 58.7^{\prime} \mathrm{E}\right), 20$ July 2017, on Populus deltoides.

Published information: Vászoly (Veszprém c. Hungary), May 2002 and June 2003, on Populus nigra (Ripka, 2004). On Populus deltoides, Bazeneh, July 2009; Arak, June 2009; Mohajeran, July 2009; Tooreh, August 2009 (Alikhani et al., 2010). On Populus alba L., Populus caspica Bornm., Populus ciliata Wall., Populus deltoides Marshall., Populus nigra L., Populus sp., Populus tremula L. without any locality data (Singh and Singh, 2017). On Populus nigra L., Populus pyramidalis Borkh. (as Populus nigra var. italica), without any locality data (Buga, 2001).

Distribution in Iran: Kermanshah, Khuzestan and other western provinces (Modarres Awal, 2002). In all areas where Populus nigra is present (Rezwani, 2004).

General distribution: Palaearctic (Europe) (Hałaj and Osiadacz, 2013). North Africa, south-west and central Asia, Pakistan, north-west India, and China (Blackman and Eastop, 2018).

Pemphigus passeki Börner, 1952

In Sexuparae, primary rhinarium on ANT VI much larger than adjacent secondary rhinaria and forming a broad band that extends over half way around antenna. Secondary rhinaria distributed III 12-16, IV 3-5, V 4-6, VI BASE 6-8 (Fig. 2) (Blackman and Eastop, 2018).

The species is holocyclic and heteroecious, alatae migrating in June-August to the basal parts and roots of Carum carvi L. The creation of galls occurs through the ballooning of the basal half of the mid-rib on Populus nigra (incl. var. italica) leaves, the swelling being broadest towards the junction with the petiole. Although galls are lengthened and extends over the midrib, they are broadest at the connection area of the stalk and lamina (Fig. 3) (Osiadacz and Hałaj, 2014).

Material examined: Ghadamgah (36 $\left.06^{\prime} 43.9^{\prime} \mathrm{N}, 5^{\circ} 03^{\prime} 10.9^{\prime \prime} \mathrm{E}\right), 18$ May 2017, on Populus nigra var. italica.

Published information: in Belarus: Minks Prov.: June 1910, Populus pyramidalis Borkh. (Buga et al., 2016). Pemphigus passeki Börner, 1952 has been recorded from Belarus for the first time on the basis of material collected in 1900 by A. K. Mordvilko. The registered diversity is less abundant than in the adjacent Poland (Buga et al., 2016).

Distribution in Iran: The first record from Iran.

General distribution: In northern Palaearctic; eastwards to Altai region of Russia (Blackman and Eastop, 2018). Finland and Ukraine, Northern Palaearctic, North-West and Central Europe (Hałaj and Osiadacz, 2013). 


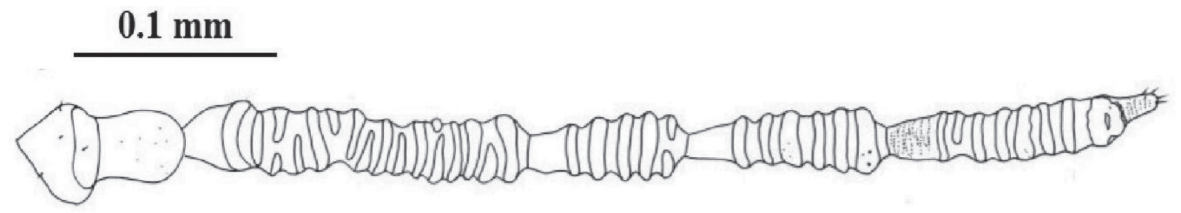

Fig. 2. Morphological traits of antennae on sexuparae of Pemphigus passeki Börner, 1952

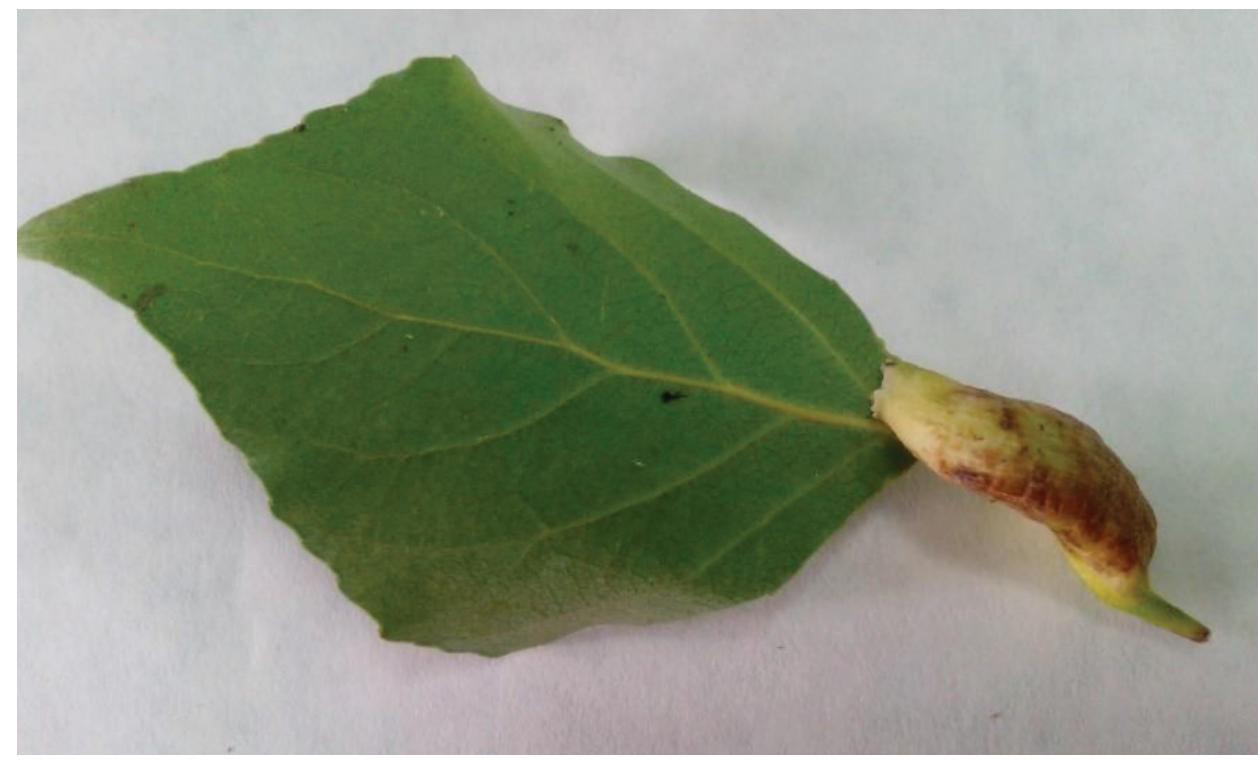

Fig. 3. Gall of Pemphigus passeki Börner, 1952, on Populus nigra var. italica, Ghadamgah, 18 May 2017 (Original picture)

Pemphigus populi Courchet, 1879

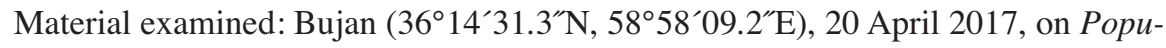
lus nigra; Sheikhha village (36 $\left.31^{\prime} 14.1^{\prime \prime} \mathrm{N}, 5^{\circ} 21^{\prime} 05.9^{\prime \prime} \mathrm{E}\right), 6$ June 2017, on Populus nigra var. italica; Chenaran (36 39 $\left.45.8^{\prime \prime} \mathrm{N}, 5^{\circ} 9^{\circ} 4^{\prime} 46.7^{\prime \prime} \mathrm{E}\right), 28$ June 2017, on Populus nigra var. italica; Ghadamgah $\left(36^{\circ} 06^{\prime} 43.9^{\prime} \mathrm{N}, 5^{\circ} 03^{\prime} 10.9^{\prime} \mathrm{E}\right), 18$ May 2017, Populus nigra var. italica; Sad Abad (36¹0`58.8”N, 58 52`14.0”E), 18 May 2017, on Populus nigra and on Populus nigra var. italica; Shirhesar (36³6 $\left.05.8^{\prime \prime} \mathrm{N}, 59^{\circ} 12^{\prime} 12.8^{\prime \prime} \mathrm{E}\right), 27$ May 2017, on Populus nigra; Toroq Forest Park (36 $\left.15^{\prime} 06.1^{\prime \prime} \mathrm{N}, 5^{\circ} 37^{\prime} 02.3^{\prime \prime} \mathrm{E}\right), 7$ April 2017, on Populus nigra var. italica.

Published information: Silesian Upland, Nida Basin and Lower Vistula Valley (Poland), June 2012, on Populus nigra (Osiadacz and Hałaj, 2014).

Distribution in Iran: Mazandaran (Modarres Awal, 2002). Baladeh in the central Alborz, Tehran (Rezwani, 2004). This species is new record for Razavi Khorasan province.

General distribution: Palaearctic, Europe and South-West and Central Asia (Hałaj and Osiadacz, 2013). In Europe, South-west and Central Asia, and eastward to China (Blackman and Eastop, 2018). 
Pemphigus populinigrae (Schrank, 1801)

The fundatrix is dark green. The apical segment of rostrum of the alate viviparous females (migrants) has even edges, usually longer than $0.1 \mathrm{~mm}$ and 0.55 times as long as the second segment of the hind tarsus and is often longer alatae, BL 1.8-2.9 mm. Apterae on secondary hosts are yellow-green, with white wax-wool, BL 2.0-2.2 mm. Sexuparae with secondary rhinaria distributed III 12-18, IV 3-7, V 4-7, VI BASE 4-7 (Fig. 4) (Blackman and Eastop, 2018).

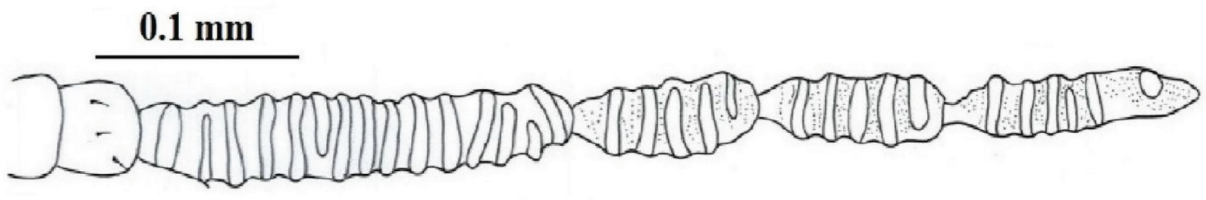

Fig. 4. Morphological traits of antennae on sexuparae of Pemphigus populinigrae (Schrank, 1801)

The species is holocyclic and heteroecious. Alatae migrating into the basal parts and leaves of Filago L. and Gnaphalium L. Sexuparae return to P. nigra in September-October, but anholocyclic overwintering apparently occurs where the primary host is not available (Mordvilko, 1935).

Galls on Populus spp., especially P. nigra, are pouch-shaped. The top part of the full-fledged galls is curved and even and has a colour of opaque slightly red with a bit yellow shade (Stroyan, 1964). The prolonged galls extending through the midrib, are more expansive than those produced by P. phenax. Such watery strumous galls, being smaller than a hazelnut, are relatively flat. The vast majority of the aforementioned galls, being merely uncovered from the bottom side of the lamina, has a clear reddish (infrequently greenish) colour, more often than not with a yellowish shade (Fig. 5) (Osiadacz and Hałaj, 2014).

Material examined: Chenaran $\left(36^{\circ} 39^{\prime} 45.8^{\prime \prime} \mathrm{N}, 5^{\circ} 04^{\prime} 46.7^{\prime \prime} \mathrm{E}\right), 28$ June 2017, on Populus nigra var. italica; Shirhesar (36³6 $\left.05.8^{\prime \prime} \mathrm{N}, 5^{\circ} 12^{\prime} 12.8^{\prime \prime} \mathrm{E}\right), 27$ May 2017, on Populus nigra.

Published information: in (Belarus): Brest Prov.: October 2016, Populus pyramidalis Borkh.; October 2015, Populus sp.; Gomel Prov.: July 2015, Populus nigra L.; Grodno Prov.: July 2016, Populus sp.; Minsk, September 2002, July 2015, August 2016, Рopulus $\times$ berolinensis Dippel, Populus nigra L. and Populus sp. (Buga et al., 2016).

Distribution in Iran: The first record from Iran.

General distribution: Throughout Europe and in north Africa, South-west Asia, Central Asia and across to east Siberia (Blackman and Eastop, 2018). Europe, N, NW and SW Asia, Sweden, Finland, Denmark, United Kingdom, Germany, Palaearctic (Hałaj and Osiadacz, 2013).

Pemphigus protospirae Lichtenstein, 1885

Material examined: Bujan (36 $\left.14^{\prime} 31.3^{\prime} \mathrm{N}, 58^{\circ} 58^{\prime} 09.2^{\prime \prime} \mathrm{E}\right), 20$ April 2017, on Populus nigra. 


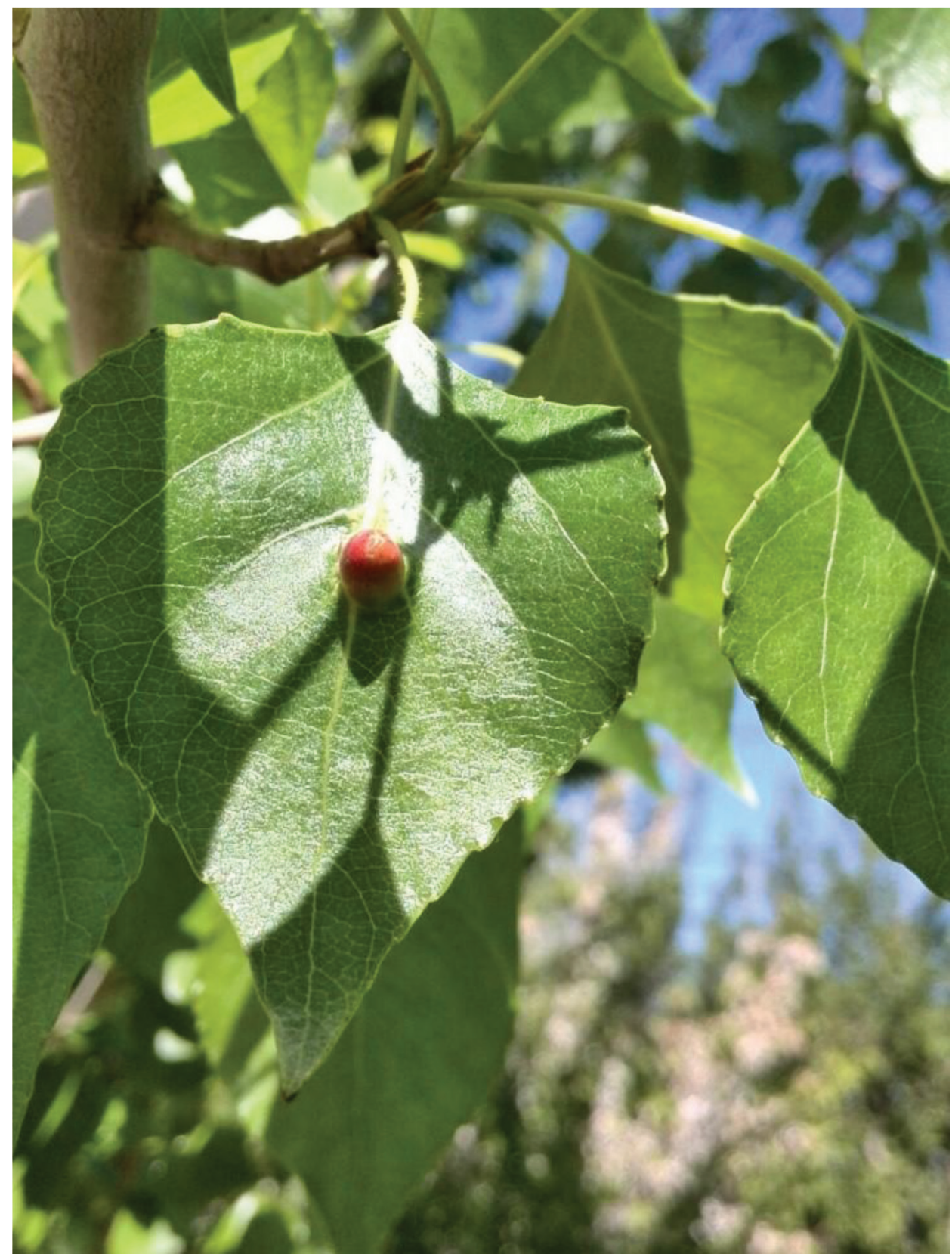

Fig. 5. Round and smooth gall of Pemphigus populinigrae (Schrank, 1801) on upper side of leaf of Populus nigra, Shirhesar, 27 May, 2017 (Original picture) 
Published information: in Belarus: Gomel Prov., July 1999, Populus nigra L., Minsk Prov.: Aug. 2015, Populus balsamifera L., 30 July 2016, Populus $\times$ berolinensis Dippel. Mogilev Prov.: Oct. 2016, Populus sp. Vitebsk Prov., Sept. 2000, Populus sp. (Buga et al., 2016).

Distribution in Iran: Central provinces (Modarres Awal, 2002). This species is new record for Razavi Khorasan province.

General distribution: Europe; recorded from West Siberia and Central Asia (Hałaj and Osiadacz, 2013). Widely distributed in Europe, also recorded from west Siberia and central Asia (Blackman and Eastop, 2018).

\section{Pemphigus spyrothecae Passerini, 1856}

Material examined: Sad Abad (36² $\left.10^{\prime} 58.8^{\prime \prime} \mathrm{N}, 58^{\circ} 52^{\prime} 14.0^{\prime \prime} \mathrm{E}\right), 18$ May 2017, on Populus nigra.

Published information: on Populus deltoides, Sar Sakhti Paein, June 2009; Gavgodar, June 2009; Kazaz Olya and Arak, September 2009; Mohajeran, July 2009 (Alikhani et al., 2010). on Populus nigra L. (Singh and Singh, 2017). In Belarus: Brest Prov.: Aug. 2016, Populus pyramidalis Borkh. Oct. 2016, Populus pyramidalis Borkh., Gomel Prov.: Sept. 2007 Oct. 2016, Populus pyramidalis Borkh. Oct. 2016, Populus pyramidalis Borkh. and Populus sp. July 2015, Populus nigra L., Minsk: Aug. 2001 and July 2015, Populus pyramidalis Borkh. and Populus sp., Minsk Prov.: July 2016, Populus $\times$ petrowskiana R.I. Schrod. et Regel. Aug. 2015, Populus sp. Oct. 2016, Populus pyramidalis Borkh. (Buga et al., 2016).

Distribution in Iran: Generally distributed (Modarres Awal, 2002).

General distribution: Palaearctic Europe, North Africa, Western Siberia; know also Pakistan and introduced to North America and Canada (Hałaj and Osiadacz, 2013; Blackman and Eastop, 2018).

\section{Pemphigus vesicarius Passerini, 1861}

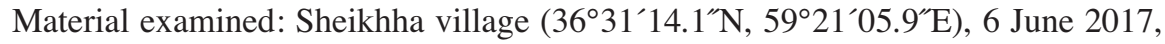
on Populus nigra var. italica; Ghadamgah (3606 $\left.43.9^{\prime \prime} \mathrm{N}, 5^{\circ} 03^{\prime} 10.9^{\prime \prime} \mathrm{E}\right), 18$ May 2017,

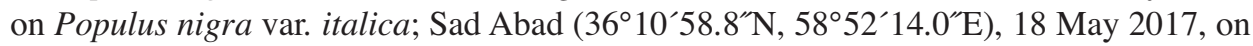
Populus nigra; Torghabeh ( $\left.36^{\circ} 18^{\prime} 33.3^{\prime \prime} \mathrm{N}, 5^{\circ} 22^{\prime} 58.7^{\prime \prime} \mathrm{E}\right), 20$ July 2017, on Populus nigra var. italica.

Published information: Vászoly (Veszprém c. Hungary), June 2003, on Populus nigra (Ripka, 2004). on Populus deltoides, Far, May 2009; Gavgodar, June 2009; Kazaz Olya, September 2009; Arak, July 2009; Mohajeran, July 2009; Bazeneh, June 2009; Tooreh, August 2009 (Alikhani et al., 2010). On Populus sp. without any locality data (Singh and Singh, 2017).

Distribution in Iran: In all areas where Populus nigra is present (Rezwani, 2004).

General distribution: Palaearctic, in Southern Europe, South-west and Central Asia, East to Pakistan and India (Hałaj and Osiadacz, 2013; Blackman and Eastop, 2018). 
Tetraneura caerulescens (Passerini, 1856)

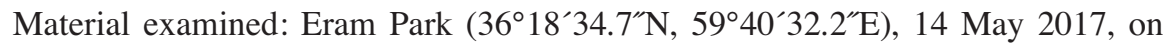
Ulmus minor; Khayyam Garden (3609'57.4”N, 58 49'18.1”E), 18 May 2017, on Ulmus glabra; Mellat Park $\left(36^{\circ} 19^{\prime} 14.7^{\prime \prime} \mathrm{N}, 5^{\circ} 32^{\prime} 17.4^{\prime \prime} \mathrm{E}\right), 15$ May 2017, on Ulmus minor; Nosrat Park $\left(36^{\circ} 16^{\prime} 33.4^{\prime \prime} \mathrm{N}\right.$, 59 40 $\left.9^{\circ} 06.3^{\prime \prime} \mathrm{E}\right), 8$ May 2017, on Ulmus minor and Ulmus glabra; Paniz (36 $15^{\prime} 38.9^{\prime \prime N}$, 59 39'10.9”E), 5 May 2017, on Ulmus glabra; Raja Park $\left(36^{\circ} 15^{\prime} 30.2^{\prime \prime} \mathrm{N}, 59^{\circ} 40^{\prime} 57.3^{\prime \prime} \mathrm{E}\right), 25$ May 2017, on Ulmus minor and Ulmus glabra.

Published information: On Ulmus minor, June 1990 and May 1991, without any locality data (Cano and Funes, 1998). Sihlea, May 2015, on Ulmus minor (Stanescu, 2009).

Distribution in Iran: In Mazandaran, Markazi and Central Alborz (Modarres Awal, 2002; Rezwani, 2004). This species is new record for Razavi Khorasan province.

General distribution: in southern and south-eastern Europe, north Africa and southwest Asia (Blackman and Eastop, 2018).

\section{Tetraneura nigriabdominalis (Sasaki, 1899)}

Material examined: Eram Park (36 $\left.18^{\prime} 34.7^{\prime \prime} \mathrm{N}, 5^{\circ} 40^{\prime} 32.2^{\prime \prime} \mathrm{E}\right), 14$ May 2017,

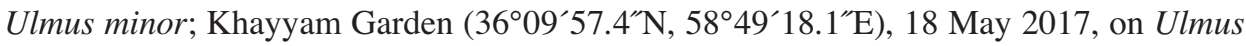
glabra; Mellat Park (36 $\left.{ }^{\circ} 19^{\prime} 14.7^{\prime} \mathrm{N}, 5^{\circ} 32^{\prime} 17.4^{\prime \prime} \mathrm{E}\right), 15$ May 2017, on Ulmus minor; Nosrat Park (36 16 33.4”N, 59 40’06.3”E), 8 May 2017, on Ulmus minor and Ulmus glabra; Paniz (36 $\left.15^{\prime} 38.9^{\prime \prime} \mathrm{N}, 5^{\circ} 39^{\prime} 10.9^{\prime \prime} \mathrm{E}\right), 5$ May 2017, on Ulmus glabra; University Campus $\left(36^{\circ} 18^{\prime} 22.4^{\prime \prime} \mathrm{N}, 59^{\circ} 31^{\prime} 59.9^{\prime \prime} \mathrm{E}\right), 20$ April 2017, on Ulmus minor; Raja Park $\left(36^{\circ} 15^{\prime} 30.2^{\prime \prime} \mathrm{N}\right.$, 5940'57.3”E), 25 May 2017, on Ulmus minor.

Published information: On Ulmus canescens, Malta-Girgenti, May 2006; Wied irRum, June 2009 and Buskett, July 2009 (Mifsud et al., 2009).

Distribution in Iran: In Mazandaran (Modarres Awal, 2002). This species is new record for Razavi Khorasan province.

General distribution: Southern and south-east Europe including Malta, south-west Asia, Georgia, Kazakhstan, China, Korea and Japan. It is also in eastern USA on U. minor and in western USA on U. pumila L. and hybrid elm (Blackman and Eastop, 2018).

Thecabius affinis (Kaltenbach, 1843)

Material examined: Jokar $\left(36^{\circ} 35^{\prime} 51.3^{\prime} \mathrm{N}, 5^{\circ} 55^{\prime} 30.9^{\prime} \mathrm{E}\right), 16$ August 2017, on Populus nigra.

Published information: Vászoly (Hungary), June 2003, on Populus nigra (Ripka, 2004). Gomel Prov. (Belarus), October 2016, on Populus nigra; July 1999, on Populus pyramidalis (Buga et al., 2016).

Distribution in Iran: Azerbaijan, Tehran and Markazi (Modarres Awal, 2002; Rezwani, 2004). This species is new record for Razavi Khorasan province.

General distribution: Europe and across Asia to east Siberia, Japan and Korea, and also in North America (Blackman and Eastop, 2018). 


\section{Discussion}

This preliminary research on gall-inducing aphids and their host plants in NE Iran added two new records of aphid species to the Iranian fauna. Previously about 485 aphid species were known from Iran (Mortazavi et al., 2015). By the present study, the Iranian aphid fauna has at least 487 species. However, the number of insects, especially aphids, recorded from Iran is still far from complete, most probably due to poor investigations and sporadic samplings in many areas. In addition, from a biogeographical point of view, it is expected that the Iranian aphid fauna would be much more diverse than what it is now due to its geographic positioning between three distinct biogeographic realms, the Palaearctic, Afrotropical and the Oriental. So, with further research on the gall-inducing arthropods, the fauna of Iran will be increased.

\section{Acknowledgements}

The authors would like to appreciate the help of Dr. Roman Hałaj (Entomological Laboratory of the Upper Silesian Nature Society of Poland) with identification of aphid species reported here. We are also grateful to Mr. Ali Mohammad Malvandi and Ms. Behnaz Bakhshi who helped us in this project. This study is a part of the MSc thesis of the first author at Ferdowsi University of Mashhad, Mashhad, Iran.

\section{Literature}

Alikhani, M., Rezwani, A., Rakhshani, E. and Madani, S. (2010): Survey of aphids (Hem., Aphidoidea) and their host plants in central parts of Iran. J. Entomol. Research 2, 7-16.

Álvarez, R., González-Sierra, S., Candelas, A. and Martinez, J. J. I. (2013): Histological study of galls induced by aphids on leaves of Ulmus minor: Tetraneura ulmi induces globose galls and Eriosoma ulmi induces pseudogalls. Arthropod-Plant Interactions 7, 643-650.

Ananthakrishnan, T. (1984): Adaptive strategies in cecidogenous insects. Biology of gall insects 52, 77-79.

Barahoei, H., Rakhshani, E., Nader, E., Starý, P., Kavallieratos, N. G., Tomanović, Ž. and Mehrparvar, M. (2014): Checklist of Aphidiinae parasitoids (Hymenoptera: Braconidae) and their host aphid associations in Iran. J. Crop Protection 3, 199-232.

Blackman, R. L. and Eastop, V. F. (2000): Aphids on the World's Crops: An Identification and Information Guide. John Wiley and Sons Ltd., 2nd ed., Chichester, 414 p.

Blackman, R. and Eastop, V. (2018): Aphids on the World's Plants: An online identification and information guide. Published online at http://www aphidsonworldsplants info/ (Accessed 25 October 2018).

Buga, S. (2001): Dendrofil'nye tli Belorusi [Dendrocolous aphids of Belarus]. Minsk: Belarusian University Publishers

Buga, S., Zhorov, D., Leshchinskaya, N. and Stekolshchikov, A. (2016): Aphids of the family Eriosomatidae (Insecta: Homoptera) in Belarus. Zoosystematica Rossica 25, 226-232.

Cano, V. S. and Funes, P. G. (1998): Estudio de los pulgones (Hemiptera: Aphididae) de la provincia de Valencia. III: Subfamilias Eriosomatinae, Anoeciinae, Thelaxinae, Myzocallidinae, Drepanosiphinae, Chaitophorinae, Lachninae y Pterocommatinae. Boletín de la Asociación española de Entomología 22, 113-123.

Chakrabarti, S. (1987): Biosystematics of gall aphids (Aphididae, Homoptera) of western Himalaya, India. Proc. Animal Sciences 96, 561-572.

Chakrabarti, S. (2007): Diversity and biosystematics of gall-inducing aphids (Hemiptera: Aphididae) and their galls in the Himalaya. Oriental Insects 41, 35-54.

Chen, J. and Qiao, G. X. (2012): Galling aphids (Hemiptera: Aphidoidea) in China: diversity and host specificity. Psyche: J. Entomology 2012, 1-12.

Floate, K. D. (2010): Gall-inducing aphids and mites associated with the hybrid complex of cottonwoods, Populus spp. (Salicaceae), on Canada's grasslands. In: J. D. Shorthouse and K. D. Floate (eds): Arthro- 
pods of Canadian Grasslands. Vol. 1: Ecology and Interactions in Grassland Habitats, Biological Survey of Canada (BSC), Chapter 13, pp. 281-300.

Foottit, R. G., Halbert, S. E., Miller, G. L., Maw, E. and Russell, L. M. (2006): Adventive aphids (Hemiptera: Aphididae) of America North of Mexico. Proc. Entomol. Society of Washington, 108, 583-610.

Ge, F., Dietrich, C. and Dai, W. (2016): Mouthpart structure in the woolly apple aphid Eriosoma lanigerum (Hausmann) (Hemiptera: Aphidoidea: Pemphigidae). Arthropod Structure and Development 45, 230-241.

Ghafouri-Moghaddam, M., Lotfalizadeh, H. and Rakhshani, E. (2014): A survey on hyperparasitoids of the poplar spiral gall aphid, Pemphigus spyrothecae Passerini (Hemiptera: Aphididae) in Northwest Iran. J. Crop Protection 3, 369-376.

Hałaj, R. and Osiadacz, B. (2013): European gall-forming Pemphigus (Aphidoidea: Eriosomatidae). Zoologischer Anzeiger. J. Comparative Zoology 252, 417-423.

Hasanshahi, G., Jahan, F., Abbasipoor, H. and Japoshvili, G. (2013): The first report of Protaphelinus nikolskajae (Yasnosh, 1963) (Chalcidoidea: Aphelinidae) parasitoid of Pemphigus immunis popular aphid from Iran. J. Plant Protection 28, 274-276.

Heie, O. E. (1993): The Aphidoidea (Hemiptera) of Fennoscandia and Denmark. V. Family Aphididae: Part 2 of tribe Macrosiphini of subfamily Aphidinae. In: Fauna Entomologica Scandinavica, Vol. 28. E. J. Brill, Leiden/New York/Köln, pp. 1-238.

Khial, B. and Sadraei, N. (1984): Poplar pests investigation in Iran. Ministry of Agriculture. Research Organization of Agriculture and Natural Resources. Research Institute of Forests and Rangelands, Technical Publication.

Mifsud, D., Pérez Hidalgo, N. and Barbagallo, S. (2009): Aphids (Hemiptera: Aphidoidea) associated with native trees in Malta (Central Mediterranean). Bulletin of the Entomol. Soc. of Malta, 2, 81-93.

Modarres Awal, M. (2002): List of Agricultural Pests and their Natural Enemies in Iran. 3rd. Univ Ferdowsi, Mashhad.

Mordvilko, A. (1935): Die Blattlause mit unvollstandigem Generationszyklus und ihre Entstehung. Fortschritte der Zoologie 8, 36-328.

Mortazavi, Z. S., Sadeghi, H., Aktac, N., Depa, Ł. and Fekrat, L. (2015): Ants (Hymenoptera: Formicidae) and their aphid partners (Homoptera: Aphididae) in Mashhad region, Razavi Khorasan Province, with new records of aphids and ant species for fauna of Iran. Halteres 6, 4-12.

Nikdel, M. and Dordaei, A. (2010): Comparison of susceptibility levels of poplar species and clones to Chaitophorus populi (Panzer) (Hem., Pemphigidae), Pemphigus spyrothecae Passerini (Hem., Aphidoidea) and Camarotoscena sp. (Hem., Psyllidae). Entomological Research 2, 241-252.

Nyman, T. and Julkunen-Tiitto, R. (2000): Manipulation of the phenolic chemistry of willows by gall-inducing sawflies. Proc. of the National Academy of Sciences 97, 13184-13187.

Nyman, T., Widmer, A. and Roininen, H. (2000): Evolution of gall morphology and host-plant relationships in willow-feeding sawflies (Hymenoptera: Tenthredinidae). Evolution 54, 526-533.

Ortego, J., Difabio, M. E. and Mier Durante, M. P. (2004): Nuevos registros y actualización de la lista faunística de los pulgones (Hemiptera: Aphididae) de la Argentina. Revista de la Sociedad Entomológica Argentina 63, 19-30.

Osiadacz, B. and Hałaj, R. (2014): First records of gall-inducing aphid Pemphigus populi (Hemiptera: Aphidoidea, Eriosomatidae) in Poland with gall-based key to Central and North European species of the genus. Entomol. Fennica 25, 16-26.

Rakhshani, E., Starý, P., Pérez Hidalgo, N., Čkrkić, J., Moghaddam, M. G., Tomanović, S., Petrović, A. and Tomanović, Ž. (2015): Revision of the world Monoctonia Starý, parasitoids of gall aphids: taxonomy, distribution, host range, and phylogeny (Hymenoptera, Braconidae: Aphidiinae). Zootaxa 3905, 474-488.

Rezwani, A. (2004): Aphids on trees and shrubs in Iran. Agricultural Research, Education Organization, Tehran, [In Persian].

Ripka, G. (2004): Recent data to the knowledge of the aphid fauna of Hungary (Homoptera: Aphidoidea). Acta Phytopathol. et Entomol. Hung. 39, 91-97.

Sabeti, H. (2002): Forests, trees and shrubs of Iran. Tehran Ministry of Agriculture and Natural Resources.

Singh, G. and Singh, R. (2017): Updated check-list of Indian Eriosomatinae (Aphidinae: Aphididae: Hemiptera) and their food plants. J. Ent. and Zool. Studies 5, 921-936. 
Stanescu, M. (2009): The catalogue of the "Dr. Marcel Brandza" zoocecidia Herbarium from the "Grigore Antipa" national museum of natural history (Bucuresti). Travaux du Muséum National d'Histoire Naturelle «Grigore Antipa», 52, 31-35.

Stone, G. N. and Schönrogge, K. (2003): The adaptive significance of insect gall morphology. Trends in Ecology and Evolution 18, 512-522.

Stroyan, H. L. G. (1964): Notes on some British species of Pemphigus Hartig (Homoptera: Aphidoidea) forming galls on Poplar, with the description of a new species. Proc. of the Royal Entomological Society of London Series B, Taxonomy; Wiley Online Library, 33, 92-100.

Suzuki, D. K., Fukushi, Y. and Akimoto, S-I. (2009): Do aphid galls provide good nutrients for the aphids? Comparisons of amino acid concentrations in galls among Tetraneura species (Aphididae: Eriosomatinae). Arthropod-Plant Interactions 3, 241-247.

Tarasi, J., Sadeghi, S. E. and Moradi, P. (2008): Study and comparing of density of spiral gall aphid, Pemphigus spyrothecae (Hom. Pemphigidae) on then clones of black poplar, Populus nigra and its natural enemies in Zanjan Province. Pajouhesh and Sazandegi 77, 130-134.

Urban, J. (2002): Occurrence, development and natural enemies of Pemphigus spyrothecae (Homoptera, Pemphigidae). J. Forest Science 48, 248-270.

Wool, D. and Burstein, M. (1991): A galling aphid with extra life-cycle complexity: population ecology and evolutionary considerations. Researches on Population Ecology 33, 307-322. 